Научная статья

УДК 316.42

DOI: $10.18101 / 1994-0866-2021-1-19-24$

\title{
CANCEL CULTURE КАК НОВАЯ СОЦИАЛЬНАЯ РЕАЛЬНОСТЬ
}

\author{
(C) Дашинимаев Гэсэр Юрьевич \\ аспирант, \\ Бурятский государственный университет имени Доржи Банзарова \\ Россия, 670000, г. Улан-Удэ, ул. Смолина 24а \\ jorafilos@gmail.com
}

\begin{abstract}
Аннотация. В работе проанализирована проблема культуры отмены (cancel culture) как новой социальной реальности, показано, как новая этика и медиасреда способны не только формировать общественные ценности, но и определять их тренды. Указывается, что благодаря развитию инфраструктуры сети Интернет и социальных сетей, cancel culture стала частью информационного пространства глобального мира. В статье уточняется содержание понятия cancel culture, осмысливаются особенности cancel culture в контексте дискурса власти, выделяется ее философская сущность. Обосновано, что новые средства и формы коммуникации создают качественно иную структуру передачи информации, где горизонтальные социальные связи способны формировать свою уникальную общественную картину мира; cancel culture превращается из формы борьбы за социальную справедливость в инструмент власти над обществом, несмотря на это, cancel culture - важный этап становления общества новой этики.
\end{abstract}

Ключевые слова: cancel culture; социальные сети; государство; общество; власть; свобода; медиатехнологии; монополии.

\section{Для цитирования}

Дашинимаев Г. Ю. Cancel culture как новая социальная реальность // Вестник Бурятского государственного университета. Философия. 2021. Вып. 1. С. 19-24.

Пятого октября 2017 г. в газете The New York Times вышла статьярасследование об известном голливудском кинопродюсере Харви Вайнштейне, в которой рассказывалось про его неоднократные домогательства к актрисам. Спустя некоторое время вышли другие издания, в которых описывали случаи насилия, когда продюсер, пользуясь своими служебными полномочия и влиянием, склонял к связи под предлогом помощи в продвижении по карьерной лестнице и получении роли в кино. Это стало началом движения \#МеТоо как реакции на проблему домогательств в киноиндустрии, движение быстро стало охватывать все сферы не только американского общества, но и большинства стран Европы.

Сотни жертв начали писать и говорить о случаях домогательств на месте работы, о насилии, дискриминации. Движение стало настолько всеохватывающим, что множество публичных персон были публично осуждены, многие рекламные контракты были разорваны, люди, которые окружали обвиненную личность, открыто заявляли, что не желают в дальнейшем иметь с ней никаких контактов. Харви Вайнштейн был лишен множества своих наград, исключен из множества 
почетных списков, он перестал существовать как успешный продюсер, заслугой которого было появление на свет ставших уже классикой кинематографа фильмов таких, как «Криминальное чтиво», «Артист», «Властелин Колец», «Король говорит» и т. д. Общество поставило на Вайнштейне жирный крест не только как на известном кинопродюсере, но и как на человеке вообще. Он перестал существовать в публичном поле. Он был выброшен из общественного. Он был «саnceled».

To cancel в переводе с английского означает аннулированный или отмененный. Словоупотребление данного слова берет свое начало из американского сленга, а его смысл заключается в том, что человек не только перестает существовать как объект социального взаимодействия, но и лишается всего хорошего, что он сделал, то есть он «отменяется».

Риск быть «отмененным» есть не только у богатых и знаменитых, он есть также у тех, кто высказывается против общественно-политического мейнстрима, а также и у тех, кто когда-то был уличен в высказываниях, дискриминирующих то или иное меньшинство, или же кто был уличен в неподобающем поведении. Эти обвинения в своем абсолютном большинстве не имеют срока давности. (Кейсы Кевина Спейси, Джеймса Ганна, Джастина Трюдо и т. д.). В прошлом году премьер министр Канады Джастин Трюдо был обвинен в расизме из-за того, что всплыла его фотография 18-летней давности, где он запечатлен в образе арабского принца в черным гриме. Это стало основанием для его обвинений в расизме с требованием публичных извинений вплоть до отставки с поста премьера, и Трюдо незамедлительно записал видеообращение, где принес извинения за свое прошлое поведение.

Cancel cultura, или культура отмены, уже стала частью современного мира, она вошла в повседневность. Cancel cultura стала важным атрибутом социальнополитического дискурса. Что такое культура отмены? Каково происхождение данного понятия? В чем причины актуализации подобной практики?

Джон МакДермотт в своей статье «Those People We Tried to Cancel? They're All hanging Out Together» определяет cancel cultura как современную форму остракизма, при которой кого-то вытесняют из социальных или профессиональных кругов - либо в социальных сетях, либо в реальном мире. О тех, кто подвергается остракизму, говорят, что они «исключены». Подобная форма остракизма является и формой бойкота, когда компания обвиняется в недопустимом поведении или высказывании, которые идут вразрез с современным культурным мейнстримом. В результате подобного бойкота «обвиняемые» оказываются за бортом современного медиапространства: если это публичное лицо, ему перестается оказываться информационное сопровождение каких-либо действий вообще. Если объект не является публичным лицом, блокируются его аккаунты в социальных сетях на основании несоответствия опубликованных постов политике компании владельца.

Cancel cultura возможна как результат информационной революции медиапространства, где современное информационное пространство формируют социальные сети, где они стали необходимым элементом, который пронизывает все 
сферы жизни современного человека. Социальные сети сегодня не простой инструмент коммуникации, но инструмент, который способен формировать и определять социальные тенденции. Ценности, которые разделяются владельцами социальных сетей, являются доминирующими в тех странах и обществах, где уровень вовлеченности общества в коммуникацию посредством соцсетей является определяющим; а это большая часть современного мира. Следовательно, мы живем в глобальном мире, в котором есть вполне конкретный набор ценностей, а также инструменты, которыми он способен подвергать остракизму тех, кто не только не разделяет, но критикует подобное состояние дел [9, с. 56]. Культура отмены является инструментом, посредством которого глобальный мир способен не только инкорпорировать свои ценности, но и защищать их.

Культура отмены - это новая форма общественного порицания, которая возможна в контексте развитого медиапространства, где социальные сети как кровеносные сосуды пронизывают информационное пространство, обеспечивая непрерывный поток коммуникации.

Вопрос об истоках культуры отмены представляет собой некоторую сложность. На данный момент не существует единого мнения относительно происхождения подобного явления, однако американские социальные психологи Джонатан Хайдс и Грег Лукианофф в работе «The Coddling of the American Mind: How Good Intentions and Bad Ideas Are Setting Up a Generation for Failur» («Изнеженность американского ума: как хорошие намерения и плохие идеи настраивают поколение на неудачу») рассуждают, что одним из истоков глобального явления cancel culture является социальная реальность американских кампусов, где в определенный момент истории стали доминировать ценности, которые они определяют как то, «что вас не убивает, делает вас слабее» [3, с. 22], «всегда доверяйте своим чувствам» [3, с. 23], «жизнь - это борьба добрых людей с хорошими» [3, с. 23-24]. Эти три суждения коренятся в неправильном восприятии мира: это три неправды, которые внушаются молодежи: неправда о хрупкости, неправда об эмоциях и наша неправда против них. Эти три фундаментальных положения провоцируют людей на то, что они не всегда готовы вступить во «взрослый мир», где наши представления редко стыкуются с реальностью.

Центральной ценностью современного американского общества стала культура безопасности во всех ее проявлениях, в том числе эмоциональная безопасность, которая заключается в ограждении и отказе идти на компромиссы с действиями и мнениями, которые идут вразрез с определенным мировоззрением, что само по себе провоцирует перманентный острый социальный конфликт [3, с. 3133]. Социальный механизм, в котором культура безопасности, возведенная в ранг абсолютной ценности целых поколений, является следствием развития современной духовной и потребительской культуры, где само понятие безопасности требует того, кто будет ее обеспечивать. Это будет государство. Государство и медиамонополисты Google, Twitter, YouTube и т. д.

Подобное положение дел усугубляется новой реальностью медиа и социальных сетей: когда кто-то сталкивается с информацией, которая не соответствует его ценностям, он добавляет ее в черный список, и она уже никогда не появится в 
новостной ленте; когда человека «банят» за оскорбления и грубость (это обычная практика). Но когда за то, что человек высказывает другое мнение, и эта практика носит массовый характер, возникает проблема, когда люди уже не всегда готовы вступать в конструктивный диалог, у многих просто-напросто отсутствуют необходимые навыки для этого [3. с. 33-35].

Взаимопонимание в обществе возможно лишь тогда, когда все его члены способны вести диалог и находить компромиссы, однако восприятие мира, где есть плохие парни и хорошие, мир, поделенный на черное и белое, неизбежно ведет к поляризации в обществе. Избыточное упрощение сложных общественнополитических процессов неизбежно ведет к генерации постоянных конфликтов и топтанию на месте в пути их разрешения. И в этом смысле бинарная оппозиция (правильное общество - общество неправильное) и ее экзальтация в форме cancel culture ведут к неизбежной конфронтации членов гражданского общества. Бинарная оппозиция - это то, что является источником власти, посредством которой создается система социального контроля [4, с. 63].

И в самом деле, общество, которое поляризовано на «правильных» ее членов и на «неправильных», способно формулировать необходимый для акторов дискурс власти, что неизбежно ведет за собой делегирование суммы гражданских прав в пользу государства, где аппарат власти выступает как исключительный в своем праве и решениях стабилизатор общественных отношений.

Разделение мира на порядок и хаос, добро и зло, на гуманизм и антигуманизм с безусловной необходимостью формирует дискурс о правильном социально-политическом устройстве и о неправильном. Бинарная оппозиция является основой христианской цивилизации, где происходит вечный процесс борьбы за правду того или иного вида. В этом заключен конфликт и вечный двигатель истории мира [4, с. 63-65]. Отметим, что в подобном восприятии мира кроится коренное противостояние с чем угодно, борьба и непримиримость есть сущность бинарной оппозиции.

Те, кто сумел обрести авторитет власти на данном явлении непримиримости, используют, осознанно или нет, природу этой сущности для того, чтобы дискурс и иерархия власти были непреложными, и для построения общества тотального контроля. Благодаря медиа и социальным сетям развитому обществу массового потребления и глобальных структур [5, с. 34] возможности для массового социального контроля являются непреложными.

Сегодня мы свидетели того, как ценности культурного мейнстрима продвигаются практически на всех популярных цифровых ресурсах, в музыке, кино и т. д. Но это вовсе не является проблемой, она появляется тогда, когда кто-то по своим причинам отказывается от так называемых общепринятых норм и на него обрушивается вся мощь репрессий массовой культуры вплоть до запрета на профессию [6, с. 73]. Было бы наивно предполагать, что политики не воспользуются столь эффективным инструментом для усиления контроля над обществом, для борьбы за голоса избирателей и поддержки в социальных сетях, для уничтожения своих оппонентов [8, с. 24]. 
Cancel culture сегодня предстает перед нашими глазами как эффективный инструмент для формирования дискурса власти, где акторы власти - партийная номенклатура, подхватывая знамя из рук различного рода борцов за социальную справедливость, - занимаются идеологической и пропагандистской работой, преследуя свои интересы. Культура отмены, начавшись как реакция на беззаконие и несправедливость, активно используется монополиями и государством для воплощения в жизнь вечного «разделяй и властвуй» [10, с. 24]. Однако, будучи в своей философской сущности воплощением бинарной оппозиции, где борьба двух полярностей является залогом для развития общества, cancel culture формирует образ будущего, образ новой этики, где общество может войти в новый этап своих общественных норм, что само по себе является важным этапом в развитии социального.

\section{Литература}

1. Васильева Е. Н. Что не так с черным гримом // BBC News. 2019. 21 сентября. URL: https://www.bbc.com/russian/features-49772809 (дата обращения: 19.09.2020). Текст: электронный.

2. John McDermott. Those People We Tried to Cancel? They're All hanging Out Together // NYTIMES. 2019. November 2. URL: https://www.nytimes.com/2019/11/02/style/what-iscancel-culture.html (дата обращения: 19.09.2020). Текст: электронный.

3. Haidt J., Lukianoff G. The Coddling of the American Mind: How Good Intentions and Bad Ideas Are Setting Up a Generation for Failure. New York City: Penguin Press. 2018. C. $22-35$.

4. Бодрийяр Ж. Символический обмен и смерть. М.: Добросвет, 2000. С. 63-65.

5. Бодрийяр Ж. Система вещей. М.: Рудомино, 1999. 218 с.

6. Бодрийяр Ж. Совершенное преступление. Заговор искусства. М.: РИПОЛ классик, Панглосс, 2019. 347 с.

7. Федотова В. Г. Информационное общество и книги для элит и масс // Общество и книга: от Гутенберга до Интернета. М., 2001. 32 с.

8. Брыгалина Ю. И. Современное общество в эпоху Интернета: проблема виртуализации // Дефиниции культуры. Томск: Изд-во Том. ун-та, 2001. 395.

9. Ветров С. А. Отчуждение в трансформируемом обществе: автореф. дис. ... канд. филос. наук. Омск, 1995. 22 с.

10. Делез Ж., Гваттари Ф. Тысяча плато: Капитализм и шизофрения. Екатеринбург: У-Фактория; М.: Астрель, 2010. 895 с.

Статья поступила в редакиию 17.11.2020; одобрена после рещензирования 23.01.2021; принята к публикациии 09.02.2021.

\section{CANCEL CULTURE AS A NEW SOCIAL REALITY}

Geser Yu. Dashinimaev

Research Assistant,

Dorzhi Banzarov Buryat State University

24a Smolina St., Ulan-Ude 670000, Russia

jorafilos@gmail.com 
Abstract. The article analyzes the problem of cancel culture as a new social reality, shows how the new ethics and media environment not only create social values, but also set their trends. Due to the development of Internet and social networks, cancel culture has become a part of the information space of the global world. The article defines the concept of cancel culture, the features of cancel culture in the context of the discourse of power, and emphasizes its philosophical essence. We come to the conclusion that new means and forms of communication create a qualitatively different structure of information transfer, where horizontal social ties are able to form their own unique social picture of the world; cancel culture turns from a means of struggle for social justice into an instrument of power over society. Despite this, cancel culture is an important stage in the development of a society of new ethics.

Keywords: cancel culture; social networks; state; society; power; freedom; media technologies; monopolies.

\section{For citation}

Dashinimaev G. Yu. Cancel Culture as a New Social Reality: A Historiosophical Analysis. Bulletin of Buryat State University. Philisophy. 2021; 1: 19-24 (In Russ.).

The article was submitted 17.11.2020; approved after reviewing 23.01.2021; accepted for publication 09.02.2021. 